\section{FACULDADE DE FILOSOFIA, CIÊNCIAS E LETRAS DE RIBEIRÃO PRETO. COMEMORAÇÕES DOS 40 ANOS DESTA FACULDADE $^{1}$}

\author{
Jorge Nassar \\ FFCLRP - Universidade de São Paulo
}

Primeiramente, meus agradecimentos pelo honroso convite feito por esta Faculdade nos seus 40 anos de existência. Vamos tentar voltar aos bons e distantes tempos de 1963 e anos seguintes, quando foi iniciada a vida desta faculdade, com a autorização de sua criação e com a conseqüente nomeação do seu primeiro Diretor, Prof. Lucien Lison.

Já em 1964 foi autorizada sua instalação e seu funcionamento.

O Prof. Lison usou o direito e o privilégio de uma lei estadual existente na época, segundo a qual o Diretor de uma entidade que estava se formando poderia, em caráter provisório e urgente, admitir ou nomear funcionários com posterior ratificação do Secretário do Estado e do Governador do Estado, para se transformar num ato perfeito. Foi o que fez o Prof. Lison em relação a Maria Ignês C. Lison, Jorge Nassar, Luiz Carlos Cagi, Demétrio Salomão (Dedé), Maria Helena Oliveira, Luiz Afonso Xavier, Maria Guidugli, Elisa Disposto, José Brites Filho, Milton A. Salomão, Maria Aparecida Ruiz e outros.

Os dois primeiros admitidos, Maria Ignês C. Lison e Jorge Nassar, tomaram posse em 2 e 6 de novembro de 1963; os outros, um pouco depois.

Já em 1964 foi feito o primeiro Vestibular. Era só alegria e emoção entre os funcionários.

Este foi dirigido pela Profa. Tereza, do Rio de Janeiro, uma pessoa que não vejo há muito tempo.

Sem materiais e locais para começar a trabalhar, o que poderíamos fazer?

Perguntamos então ao Prof. Lison - Como e onde vamos trabalhar? - Ele nos disse:

"Vamos pedir ajuda à Faculdade de Medicina. Em último caso, se não conseguirmos, arranjaremos caixas de madeira, bancos, máquinas de escrever

\footnotetext{
${ }^{1}$ Depoimento apresentado durante a Sessão Solene da Congregação da Faculdade de Filosofia, Ciências e Letras de Ribeirão Preto, realizada em 31/03/2004, para abertura oficial das comemorações dos 40 anos da Faculdade.
}

usadas e colocaremos nos corredores para iniciar nossa luta e nosso desafio".

Estes foram grandes, mas valeram a pena. E assim começou a luta, com a ajuda da Faculdade de Medicina. A Diretoria e a Secretaria ficaram nas duas primeiras salas do Depto. de Bioquímica. As demais seções (Tesouraria, Compras, Alunos, Pessoal, Almoxarifado, Oficina de Precisão e Contabilidade) foram localizadas nas correspondentes seções da Faculdade de Medicina e Hospital das Clínicas. E assim começou a vida Administrativa da FFCLRP e as primeiras dificuldades foram aparecendo e sendo vencidas.

A FFCLRP era enquadrada nesta época, como instituto isolado de ensino superior, subordinada à CESESP, Secretaria da Educação, na parte Administrativa e à Secretaria da Fazenda e Tribunal de Contas na sua parte financeira e fiscalização. Estes eram os locais procurados, a cada 15 e 20 dias, para auxílios, instruções e liberação de recursos financeiros.

Até o dia 20 de cada mês era entregue na Secretaria da Fazenda a Programação Financeira para o mês seguinte, sendo liberada no final do mês, para pagamento de pessoal e de fornecedores.

Às vezes, a importância liberada era menor do que a necessária. Na Secretaria da Fazenda era o local do choro do famoso "duodécimo financeiro", feito pelos funcionários responsáveis e pelo Sr. Diretor.

Fazíamos também a elaboração do Orçamento Programa, para o ano seguinte. Era um trabalho enorme e exaustivo, que nos requisitava por um mês, com discriminação de todo material e pessoal necessários para toda a Faculdade, com a devida justificativa.

As idas e vindas a São Paulo eram feitas de ônibus, pois não tínhamos sequer um veículo, o qual somente foi adquirido alguns anos depois (automóvel DKW).

Quando uma reunião era solicitada por nós com o Prof. Lison para solução, discussão de problemas e autorização de pedidos, ele respondia: "Se você não quer resolver um problema, nomeie uma Comissão e convoque uma reunião”. Isto se chama empurrar com a barriga - cada um deveria ser responsável pela sua seção.

Mais tarde, com a construção dos primeiros blocos, A, B, C, as instalações foram melhorando. E, nesses anos de vai e vem a São Paulo, muitos fatos 
engraçados e pitorescos aconteceram:

a) Mariza, Dedé, Benedito e Jorge estavam sentados no Largo do Arrouche, de manhã, em frente à Secretaria da Educação, esperando o horário. Uma senhora idosa passou ao lado e deixou cair da bolsa uma nota de dinheiro. Gentilmente, o Dedé agachou para pegar a nota. Eis que a senhora pisa na nota e pede socorro, xingando, gritando e chamando-o de ladrão. Dedé ficou muito nervoso e constrangido.

b) Certo dia, Dedé e eu fomos de caminhoneta com o Prof. Lima Verde para São Paulo e ele nos deixou na Secretaria da Educação e foi para o Butantã. Ele lotou de caixas com cobras a carroceria e a cabine. Foram quatro horas de viagem e nós ficamos assustadíssimos, embora o Prof. afirmasse que as cobras não eram venenosas.

c) Às vezes, quando chovia muito nas viagens a São Paulo, entrava água no carro DKV na estrada. Era muito desconfortável.

d) Este outro fato foi contado pelo Dedé, mas eu não estava presente. Mariza, Maria Ignês e Dedé foram certa vez ao Tribunal de Contas. O prédio era moderno e quando o elevador chegava ao andar solicitado, abria a porta e anunciava o número do mesmo. Maria Ignês teria comentado: "Este elevador fala”. Todos riram. Provavelmente foi mais uma brincadeira do querido Dedé.

Muitos outros fatos aconteceram, mas se perderam na memória, nas lembranças e no tempo. Havia um bom entendimento entre funcionários e professores, todos jovens na época. Todos lutavam com vontade, responsabilidade, alegria e dignidade. Bons tempos foram aqueles, vividos nos primeiros anos desta querida Faculdade. Pessoalmente, foram na FFCLRP os meus melhores tempos vividos dentro de uma vida funcional de 37 anos de serviços.

Passados alguns anos, em 1975, houve a integração desta Faculdade na USP e no Campus de Ribeirão Preto. A maioria dos funcionários foi transferida para a administração do Campus, sem ao menos serem consultados, se aceitariam ou não.

Senhor Diretor, muito emocionado, tentei relembrar um pouco desta querida Faculdade, nos seus cinco primeiros anos de funcionamento, período de 1963 a 1968. As dificuldades, os obstáculos, a pouca experiência de nós, funcionários, tudo isto concorreu para que optasse por este período, para que o sabor da vitória fosse mais doce.

Senhor Diretor, para encerrar, pediria licença para relembrar e homenagear meus queridos colegas e companheiros desta época, já falecidos, citando seus nomes: Prof. Lison, Luiz C. Cagi, Demétrio M. Salomão (Dedé), Maria Ap. Ruiz (Cida), Luiz A. Xavier, José Brites Filho, Atílio Lazarini Neto, Milton A. Salomão, da FFCLRP e também: Paulo Biagini, Emir Garcia e Emílio Negri, da Faculdade de Medicina, que muito nos ajudaram.

Estes já se foram e somente a saudade restou. Muito obrigado. 